\title{
Growth efficiency, growth rate and the remineralization of organic substrate by bacterioplankton - revisiting the Pirt model
}

\author{
Ramón Cajal-Medrano ${ }^{1,2}$, Helmut Maske ${ }^{1, *}$ \\ ${ }^{1}$ Ecología, Centro de Investigación Científica y Educación Superior de Ensenada (CICESE), Apdo Postal 2732, Ensenada, \\ CP 22880, Baja California, Mexico \\ ${ }^{2}$ Facultad de Ciencias Marinas, Universidad Autónoma de Baja California, Apdo Postal 453, Ensenada CP 22880 , \\ Baja California, Mexico
}

\begin{abstract}
The growth yield of aquatic bacteria plays a critical role in the biogeochemical cycle of organic carbon in the sea. The Pirt model (1982) proposes a relationship of specific growth rate $\left(\mu, \mathrm{d}^{-1}\right)$, respiration rate $\left(r, \mathrm{~d}^{-1}\right)$ and growth yield ( $Y$, unitless) of bacteria when the growth rate is limited by the concentration of the organic substrate and carbon stoichiometry is applied. Published data from natural populations of bacterioplankton within a temperature range of 10 to $25^{\circ} \mathrm{C}$ follow the Pirt model, where the growth yield is approaching asymptotically a maxımum value $(\varepsilon)$ with increasing growth rate. The specific rate of the maintenance metabolism $\left(a_{,} d^{-1}\right)$ is the shape factor defining the curve. From the model a relationship between the specific respiration rate and the grow th rate $\{r=[\mu(1 / \varepsilon-1)+a / \varepsilon]\}$ can be derived. Based on the published data these model parameters were estimated: $\varepsilon=0.51$ and $a=0.58$. Our model results should help explain the wide range of growth efficiencies reported for natural bacterioplankton.
\end{abstract}

KEY WORDS: Bacterioplankton · Growth efficiency - Respiration rate · Growth rate

\section{INTRODUCTION}

The efficiency of bacteria to consume dissolved organic carbon and to convert it into bacterial biomass ultimately defines their predominant role as mineralizers or biomass producers. This has been paraphrased as the 'link or sink' for organic matter in the ocean (Jumars 1993). The carbon conversion efficiency of marine bacteria greatly depends on the respiration rate, a crucial variable in the budget of the marine carbon cycle (Cole \& Pace 1995, Jahnke \& Craven 1995). A wide range of values has been reported in the literature, from 0.03 to 0.85 . Cole \& Pace (1995) showed that the values most frequently reported in the literature are between 0.30 and 0.60 . There are many physiological conditions known to alter the growth efficiency of bacteria such as cellular synthesis, extracellular poly-

·Addressee for correspondence. E-mail: hmaske@cicese.mx mer formation, excretion of low molecular weight metabolites, maintenance functions and regulatory processes (Neijssel et al. 1996). Sherr \& Sherr (1996) recently suggested that seasonal differences in the growth efficiency may help to explain the temporal of set in oceanic production and respiration. However, there is no published information on the parameters that are driving the bacterial growth efficiency in the ocean ecosystem.

The carbon conversion efficiency or bacterial growth efficiency can be expressed as the growth yield, $Y$, the ratio of organic substrate utilized by bacteria $(S$, substrate carbon) that is converted into bacterial biomass $(X$, biomass carbon), i.e. $Y$ is unitless. Models for bacterial utilization of carbon have been developed by various authors, ranging from the very simple models with 3 state variables (Pirt 1975) to very complex bioenergetic models with 6 state variables (Vallino et al. 1996). None of these models have been used to explain the general patterns of growth yield in the ocean. 


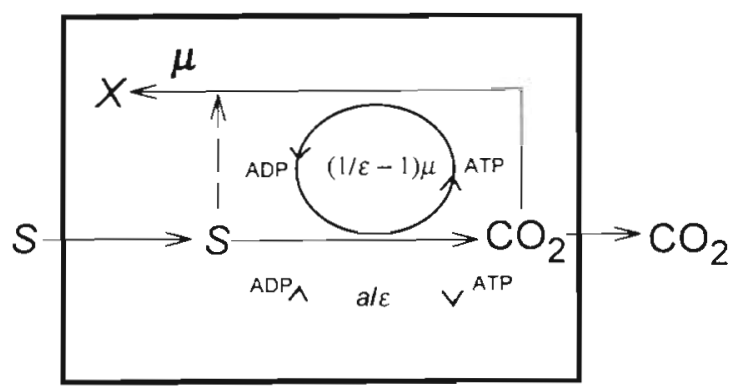

Fig 1. Organic substrate processing by the bacterial cell according to the Pirt model. The substrate, $S_{1}$ is incorporated into the cell, the major fraction is respired to carbon dioxide. According to the model the fraction of the substrate that is directly transformed into biomass (dashed arrow) is insignificant. Part of the respiration is supporting the cellular maintenance $(a / \varepsilon)$, indicated by the gray circle, and the other part the biosynthesis $(1 / \varepsilon-1) \mu$ (black circle). $\mu$ : formation of bio-

mass $X$, predominantly by de novo synthesis from $\mathrm{CO}_{2}$

Below, the Pirt model is used to interpret published data obtained with natural bacterial populations from temperate, pelagic systems.

The most simple form of Pirt's $(1975,1982)$ model is considering the following state variables: organic substrate, bacterial biomass and respired carbon. Organic carbon is taken here as a metabolic energy substrate. The Pirt model was developed for conditions where bacterial growth rate is limited by organic carbon, which is probably a common condition in seawater (Morita 1997). For those waters where nitrogen or phosphorus limitation of bacterial growth rate has been documented (Horrigan et al. 1988, Kuparinen \& Heinänen 1993, Zweifel et al. 1993, Rivkin \& Anderson 1997) the specific form of model discussed below would not be applicable. Pirt (1975) also considered the case of growth rate limitation by inorganic nutrients, but this case will not be considered here. In the case of literature data obtained with natural seawater cultures the possibility of inorganic nutrient limitation cannot be automatically excluded. Experiments where organic substrate was added might be even more likely to lead to inorganic nutrient limitation, at least in the final stages of the logarithmic growth phase.

The Pirt model is built upon the concept that under aerobic conditions the organic substrates are taken up and mainly respired, thus providing metabolic energy (ATP) and reduction equivalents. A minor fraction of organic substrate is used directly or in modified form as biomass, as indicated in Fig. 1 by the dashed arrow, but this route is considered insignificant in the model below. The respiration products are used in principle to synthesize biomass (anabolism, solid line circle in Fig. 1), and to provide energy for the physiological activities that maintain the integrity of cellular bio- mass, i.e the turnover of cellular constituents, ionic equilibrium and repair processes (gray line circle in Fig. 1). The energy expended on cell movement might be subsumed under the maintenance metabolism. The model assumes a constant specific rate of respiration serving maintenance; this rate is expected not to change with the specific growth rate under conditions of growth rate limitation by organic carbon. According to the Pirt model $(1975,1982)$ the consumption of organic carbon ( $d S$ ) equals gross bacterial production, which is the sum of anabolic bacterial growth or net growth $(d X)$ and the remineralized carbon $\left(d R, \mathrm{CO}_{2}\right.$ liberated).

$$
d S=d X+d R
$$

The bacterial growth efficiency $(Y)$ is the ratio of net production or growth $(d X)$ to gross bacterial assimilation $(d S)$ (Pirt 1975, 1982). If $X$ equals bacterial biomass

$$
Y=\frac{d X}{d S}
$$

Therefore

$$
Y=\frac{d X}{d X+d R}
$$

if

$$
\mu=\frac{d X}{X t}
$$

and

$$
r=\frac{d R}{X t}
$$

then

$$
Y=\frac{\mu}{\mu+r}
$$

implying that growth efficiency is determined by the ratio of growth rate to remineralization rate. Above, an ideal substrate has been considered that could be converted completely to biomass, with $r$ being independent of the growth rate and with a maximum stoichiometric efficiency of $Y$ given by $\mu_{\max } /\left(\mu_{\max }+r\right)$. Pirt (1982) presented a more general model, introducing a maximum obtainable yield at maximum growth rates and a growth rate independent basal respiration rate serving the maintenance metabolism. This maximum obtainable yield, $Y_{E G}$ (Pirt 1975) or $Y_{G}$ (Pirt 1982), was conceptually related to the nutritional quality of the substrate. Here we will be using instead the unitless efficiency factor, $\varepsilon$, that defines the biosynthesis efficiency of the substrate into biomass or into energy equivalents for maintenance respiration because it is not the maximum growth efficiency that is defining the substrate allocated to the maintenance metabolism but the efficiency with which the substrate can be converted. According to the model, the specific rate of utilization of the energy source $d S$ is distributed into 2 routes for energy utilization leading to 2 different but 
related coefficients: a constant maintenance energy coefficient and a growth rate dependent maintenance energy coefficient. Both processes are indicated by separate cycles in Fig. 1. The substrate demand for both processes can be defined as the substrate equivalents for cellular maintenance, $d A / \varepsilon$, and those to support biosynthesis, i.e. the interconversion of substrate into biomass, $d X / \varepsilon$. If applied to Eqs. (1) and (2) we get:

$$
Y=\frac{d X}{\frac{1}{\varepsilon}(d X+d A)}
$$

To simplify the units, $d A$ is used here as energy equivalents of carbon dioxide liberated by the oxidation of an ideal organic substrate $(\varepsilon=1.0)$. Note that $d A / X$ is still assumed to be constant for a specific organic substrate and independent of the growth rate as long as this substrate is limiting the growth rate. Pirt (1975) and, in a similar model. Thingstad (1987) considered the efficiency factors for $d X$ and $d A$ in Eq. (7) as independent. Because there is no experimental information available that would allow the separate evaluation of these 2 processes, it will be assumed below that both processes have the same efficiency factors.

In Eq. (7) the consumption of organic substrate was determined by a constant energy demand for maintenance metabolism, (1/ع)dA (cf. Fig. 1), and the conversion of substrate into biomass, $(1 / \varepsilon) d X$ (cf. Fig. 1). The latter term includes the biomass formed, $d X$, and the organic substrate remineralized to provide the energy for biomass synthesis, $(1 / \varepsilon) d X-d X$

$$
\frac{1}{\varepsilon} d X=d X+\left(\frac{1}{\varepsilon}-1\right) d X
$$

The oxidation of organic substrate or production of $\mathrm{CO}_{2}(d R)$ depends on the maintenance energy plus energy used in biomass synthesis; therefore $d R$ would then be

$$
d R=\frac{1}{\varepsilon} d A+\left(\frac{1}{\varepsilon}-1\right) d X
$$

Respiration will oxidize a variable portion of assimilated dissolved organic carbon (DOC) to $\mathrm{CO}_{2}$ and lead to the concurrent consumption of $\mathrm{O}_{2}$. The respiration quotient (RQ) can probably vary with the efficiency factor if $\varepsilon$ is dependent on the digestibility or the state of reduction of the organic substrate. Solving Eq. (8) for $d X$ and substituting the right-hand part of Eq. (9) for $d R$ in Eq. (3) yields

$$
Y=\frac{d X}{\frac{1}{\varepsilon} d X+\frac{1}{\varepsilon} d A}
$$

Eqs. (6), (7) \& (10) can be recast in terms of specific growth $\mu$ and specific respiration rates. $a$ is the specific rate of the oxidation of organic carbon to serve the energy demand for cellular maintenance $\left[d A(X t)^{-1}\right]$ (Pirt 1982). The rate of $a$ is in reference to a hypothetical substrate that could be respired with $100 \%$ efficiency.

$$
Y=\frac{\mu}{\frac{1}{\varepsilon} \mu+\frac{1}{\varepsilon} a}
$$

Eq. (9) can be expressed in terms of specific rates $\left(\mathrm{d}^{-1}\right)$, where $r\left[d R(X t)^{-1}\right]$ is the specific rate of cellular $\mathrm{CO}_{2}$ production.

$$
r=\frac{1}{\varepsilon} a+\left(\frac{1}{\varepsilon}-1\right) \mu
$$

The specific respiration rate, $r$, can be calculated from the measured growth yield and the growth rate by solving $r$ from Eq. (6)

$$
r=\frac{\mu}{Y}-\mu
$$

It is clear from Eq. (13) that $r$ will increase linearly with the growth rate.

\section{RESULTS}

Data of growth efficiency, respiration and growth rate of pelagic marine and freshwater bacteria under organic substrate limitation, and non-organic carbon limitation were taken from the published literature. The Pirt model (1975) was developed mainly from data obtained with continuous cultures, which by definition are substrate limited. The specific model applied here is only applicable to conditions of energy substrate, i.e. organic carbon limitation. Even though a good number of data of growth efficiency have been published (see Jahnke \& Craven 1995, Carlson \& Ducklow 1996), not many data sets include the specific growth rate. The published data chosen by us included the variables growth efficiency and specific growth rate, or these variables could be computed by us from other data provided in the publications. In an effort to include as many data sets as possible, some data obtained after the addition of organic carbon were included, but only those where inorganic nutrient limitation was deemed unlikely. Data from cultures where inorganic nutrients were added were included in the list because the addition of inorganic nutrients would not cancel the organic substrate limitation. The specific growth rate, $\mu\left(\mathrm{h}^{-1}\right)$, is reported as the logarithm (base e) of the biomass increase over time. In Table 1 some aspects of the methodology used to obtain the data in the different publications are provided for comparison.

Goldman \& Dennet (1991) prepared batch cultures with natural bacteria populations from artificial seawa- 
Table 1. Comparison of the methods used to obtain the specific growth rate and the growth efficiency

\begin{tabular}{|c|c|c|}
\hline Source & Specific growth rate calculation & Growth efficiency calculation \\
\hline Goldman \& Dennet (1991) & Logarithmic particulate carbon growth & $Y=\Delta \mathrm{POC} / \triangle \mathrm{DOC}$ \\
\hline Blum \& Mills (1991) & $\begin{array}{l}\text { Turnover time } \\
\mu=1 / \text { turnover time } \\
\mu=\left(\mathrm{T}^{*} f_{1}\right) /(\text { cell } \Delta t)\end{array}$ & $Y=\mathrm{BV} f_{2} /\left(\mathrm{BV} f_{2}+\mathrm{RQ}_{1} \Delta \mathrm{O}_{2}\right)$ \\
\hline Middelboe et al. (1992) & Dilution rate of continuous culture & $Y=\Delta \mathrm{POC} /(\triangle \mathrm{POC}+\Delta \mathrm{DIC})$ \\
\hline Middelboe \& Søndergaard (1993) & $\mu=\left(\mathrm{T}^{\bullet} f_{3}\right) /($ cell $\Delta \mathrm{t})$ & $Y=\Delta \mathrm{POC} /\left(\Delta \mathrm{POC}+\mathrm{RQ}_{2} \Delta \mathrm{O}_{2}\right)$ \\
\hline Carlson \& Ducklow (1996) & Logarithmic cell growth and culture cell volume growth & $Y=\Delta \mathrm{B} f_{4} / \Delta \mathrm{DOC}$ \\
\hline Kristiansen et al. (1992) & Dilution rate of continuous culture & $Y=\Delta \mathrm{POC} /(\triangle \mathrm{POC}+\Delta \mathrm{DIC})$ \\
\hline \multicolumn{3}{|c|}{ cell $\left(\right.$ cell $\left.\mathrm{ml}^{-1}\right)=$ concentration of bacterial cells } \\
\hline \multicolumn{3}{|l|}{$\mathrm{BV}\left(\mu \mathrm{m}^{3}\right)=$ biovolume } \\
\hline \multicolumn{3}{|c|}{$\begin{array}{l}\text { DOC }(\mu \mathrm{M})=\text { dissolved organic carbon measured by organics added minus residual concentr } \\
\text { or by HTCO (high temperature combustion) (Carlson \& Ducklow 1996) }\end{array}$} \\
\hline \multicolumn{3}{|c|}{$\mathrm{DIC}(\mu \mathrm{M})=$ total inorganic carbon concentration measured by IRGA (infrared gas analyzer) } \\
\hline \multicolumn{3}{|c|}{$\Delta \mathrm{O}_{2}(\mu \mathrm{M})=$ change in dissolved oxygen concentration } \\
\hline \multicolumn{3}{|c|}{ POC $(\mu \mathrm{M})=$ particulate organic carbon measured by CHN analyzer } \\
\hline \multicolumn{3}{|c|}{$\mathrm{RQ}_{1}=\Delta \mathrm{CO}_{2} / \Delta \mathrm{O}_{2} ; \mathrm{RQ}_{1}=1.0, \mathrm{RQ}_{2}=0.82$} \\
\hline \multicolumn{3}{|c|}{$\mathrm{T} \cdot\left(\mathrm{M} \mathrm{h}^{-1}\right)=$ thymidine incorporation } \\
\hline \multicolumn{3}{|c|}{$f_{1}=1.3 \times 10^{18}$ cells $\left(\mathrm{mol}^{3} \mathrm{H}-\mathrm{TdR} \text { incorporated }\right)^{-1}$} \\
\hline \multicolumn{3}{|c|}{$f_{2}=354{\mathrm{fg} \mathrm{C} \mu \mathrm{m}^{-3}}^{2}$} \\
\hline \multicolumn{3}{|c|}{$f_{3}=2 \times 10^{18} \mathrm{cells} \mathrm{mol}^{-1}$ of thymidine incorporated } \\
\hline
\end{tabular}

ter, measuring biomass as particulate organic carbon, and they calculated the organic substrate incorporated from the organics added to the media and the residual concentration. Specific growth rate was calculated by regression analysis of the exponential portion of the curve ln POC versus time. The data on specific growth rate were taken from Goldman \& Dennet's Table 1 and the corresponding growth efficiency from their Table 3 . The experimental temperature was $24^{\circ} \mathrm{C}$.

Blum \& Mills (1991) used biodegraded seagrass as an organic substrate in their experiments with natural bacterial populations from Chesapeake Bay. Specific growth rate was measured by cell counts and thymidine incorporation, biomass by cell counts and microphotometric evaluation of biovolume using a conversion factor of $0.354 \mathrm{pg} \mathrm{C} \mathrm{m}^{-3}$, and respiration by oxygen consumption with a respiration quotient (RQ) of 1.0. The growth rate was calculated as the inverse of bacterial turnover time in their Fig. 2a and bacterial growth efficiency $Y$ is taken from their Fig. 2b. The text does not indicate the temperature, but we suggest that the temperature was within the range of temperatures given by the other authors, between 10 and $25^{\circ} \mathrm{C}$.

Middelboe et al. (1992) prepared batch and continuous cultures inoculated with natural populations from an estuary. $\mu$ was calculated from the generation time $(g)$ in their Table 2, applying $\mu=0.693 / \mathrm{g}$. Growth efficiency (Eq. 3) was calculated from net production and respiration data in the same table. Respiration was measured by changes in inorganic carbon and biomass production from particulate organic carbon. Bacterial carbon content was measured by cell counts and POC determination using a factor of $42 \pm 7$ to $56 \pm 10 \mathrm{fg} \mathrm{C}$ cell ${ }^{-1}$. The temperature ranged from 10 to $19^{\circ} \mathrm{C}$ during the measurements.

In the Middelboe \& Søndergaard (1993) study, batch cultures were inoculated with a natural bacterial population from a freshwater lake to obtain bacterial biomass and bacterial production (their Fig. 2) and the corresponding bacterial growth efficiency (their Fig. 3a). The respiration was calculated from the oxygen consumption using an $R Q$ of 0.82 . The temperature during the experiments was $18^{\circ} \mathrm{C}$.

Carlson \& Ducklow (1996) used Sargasso Sea water for batch cultures, measuring the biovolume for biomass estimates and organic substrate incorporated was measured as DOC consumption during the log phase of batch culture growth. Their data for specific growth rate (their Table 3, column 'Growth property' and 'Abundance') and growth efficiency from each treatment were used. The temperature for their measurements varied between 19 and $25^{\circ} \mathrm{C}$.

Kristiansen et al. (1992) calculated growth efficiencies in continuous freshwater cultures obtained with enriched, normal and aged lake water after removal of $\mathrm{CO}_{2}$ and $\mathrm{pH}$ adjustment. Data of growth efficiency and specific growth rate were taken directly from their 


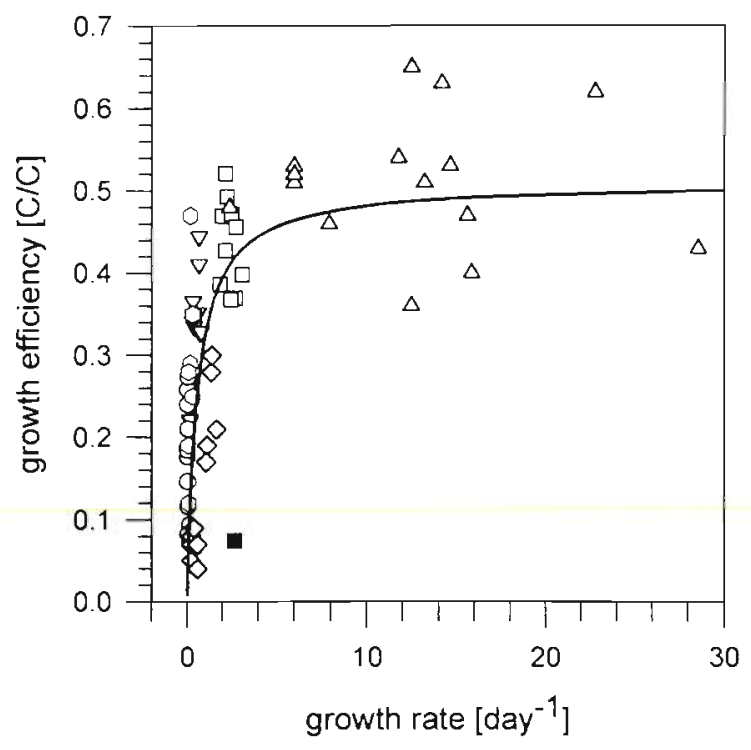

Fig. 2. Growth efficiency versus specific growth rate taken from published data. $O$ (Blum \& Mills 1991), $\Delta$ (Goldman \& Dennet 1991), $\nabla$ (Middelboe et al. 1992), $\square$ (Middelboe \& Sondergaard 1993), $\diamond$ (Carlson \& Ducklow 1996), $\diamond$ (Kristiansen et al. 1992), outlier (Middelboe \& Sondergaard 1993) The line represents the growth efficiency modeled with $a=$ 0.58 and $\varepsilon=0.51$

Table 4. Specific growth rate was calculated from their generation time (Table 4) applying $\mu=0.693 / \mathrm{g}$. The temperature was about $10^{\circ} \mathrm{C}$.

The data from the above publications are presented graphically in Fig. 2. The data show a steep increase in $Y$ at very low growth rates and an asymptotic approach to a maximum growth efficiency of approximately 0.5 at higher growth rates. The general pattern of the data distribution suggested that the data could be interpreted by the Pirt model. Scatter of the data (Fig. 2) is expected because they were obtained in different environmental situations and with different methodologies. The different data sets were taken at temperatures ranging from 10 to $25^{\circ} \mathrm{C}$; however, the data do not show any obvious co-variation with temperature.

Eq. (12) can be plotted with $r$ on the ordinate and $\mu$ on the abscissa, with a slope of the gradient $(1 / \varepsilon)-1$ and an intercept of $a / \varepsilon$ (Fig. 3). A linear regression of all the data presented in Fig. 2 yielded a slope $10.98 \pm$ $0.09, \mathrm{n}=76, \mathrm{p}<0.01)$ and intercept $(1.55 \pm 0.6, \mathrm{n}=76$, $\mathrm{p}<0.01$ ). One data point taken from Middelboe \& Søndergaard (1993) in Fig. 2 and Fig. 3 (filled square) is an obvious outlier in comparison to the other data in the figures. This data point already deviated from the trend in the original time series (Middelboe \& Søndergaard 1993, Fig. 3) and we decided to calculate the regression slope in Fig. 3 again without this data point, resulting in a slope of $0.98 \pm 0.06(n=75, p<0.01)$ and an intercept of $1.14 \pm 0.4(\mathrm{n}=75, \mathrm{p}<0.01)$. The reason

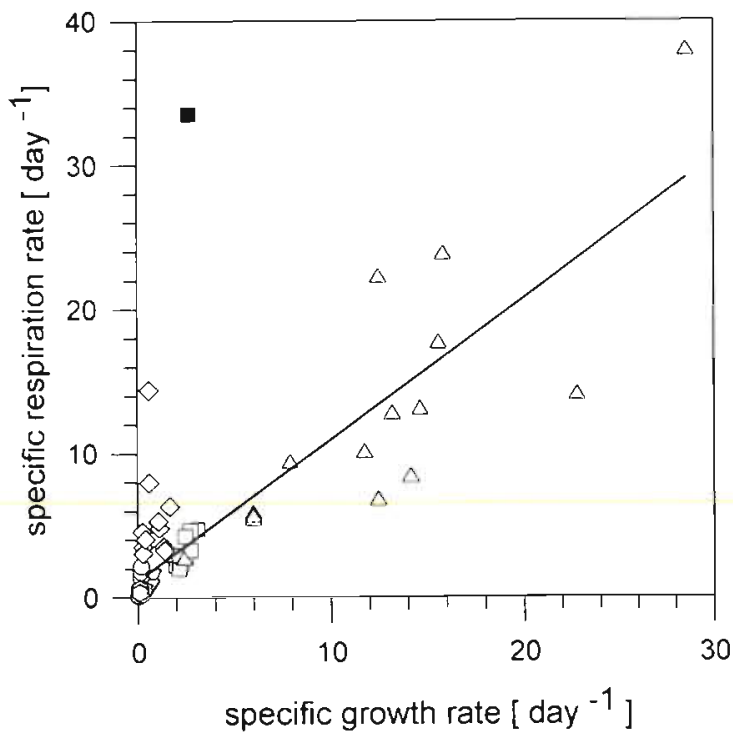

Fig. 3. Respiration versus growth rate. Respiration was calculated using Eq. (12). Linear regression yielded a coefficient of determination, $\mathrm{r}^{2}=0.77(\mathrm{n}=75, \mathrm{p}<0.01)$ with a slope of 0.98 $\pm 0.06(p<0.01)$ and an intercept of $1.14 \pm 0.4(p<0.01)$ from the whole data set minus the outlier (घ). Symbols are the same as in Fig. 2

for excluding this single data point was not so much to increase the statistical significance of the data set but to avoid a bias in the quantitative estimate of the parameter values. All further data analysis was done with the data set where the 1 data point was excluded. From the slope $\varepsilon$ was calculated as 0.51 and from the intercept a was estimated as 0.58 . From these parameter values and Eq. (12), the respiration rate $\left(\mathrm{C}_{\mathrm{CO}_{2}} \mathrm{C}_{\text {bromass }}{ }^{-1}\right.$ $\mathrm{d}^{-1}$ ) can be expressed as:

$$
\Gamma=\mu+1.1
$$

From Eqs. (6) and (14), $Y$ can be modeled as a function of growth rate and compared to the published values (Fig. 2). The comparison shows considerable noise at low growth yields, i.e. at low growth rates, yielding a low determination coefficient, $\mathrm{r}^{2}=0.57$. The growth yield published and that calculated from the growth rate using Eqs. (6) \& (13) are compared in Fig. 4. The intercept and slope in Fig. 4 are not significantly different from 0 and 1 respectively. In the figure the data by Carlson \& Ducklow (1996) tend to lie systematically on one side of the regression line. The comparison of the respiration rate estimated from the published growth rate and yield, and the modeled respiration rate (Fig. 5) yielded a determination coefficient of 0.77 without a significant difference in the slope from 1 and in the intercept from 0. Again the data by Carlson \& Ducklow (1996) appear to be separate from the other data. 


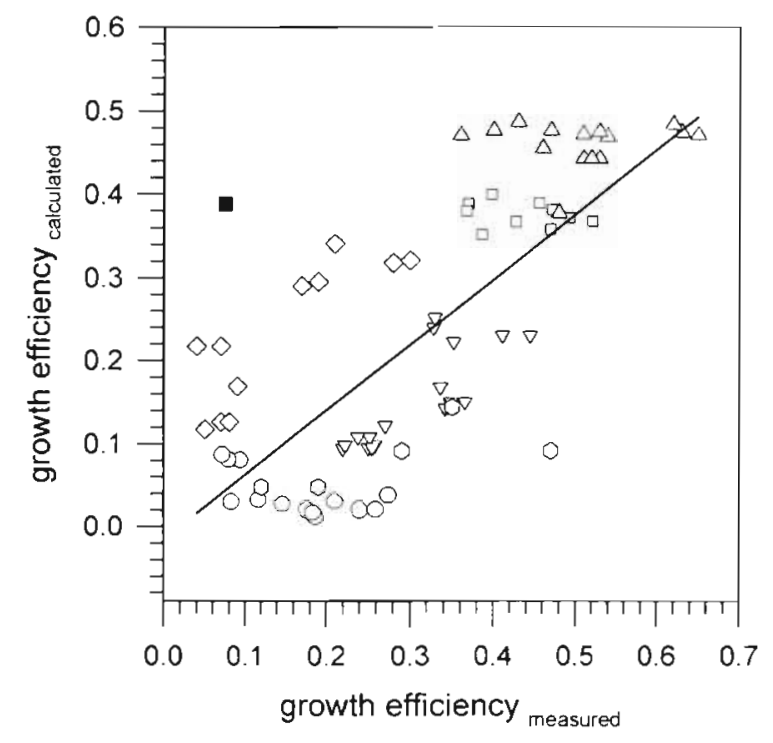

Fig. 4. Comparison of measured and calculated growth efficiency. $r^{2}=0.58(n=75)$ and the intercept and slope are not significantly different from 0 and 1 respectively. Symbols are the same as in Fig. 2

\section{DISCUSSION}

The model applied here assumes growth rate limitation by organic substrate, but the model does not calculate growth rate from ambient conditions and no mechanisms for the growth rate limitation by organic substrate are assumed. The model is inherently boundary-limited at very low growth rates, because the physiological behavior of bacterial cells in this range is little known and can vary strongly. There are reports for continued respiration of bacteria during no growth (Nyström \& Kjelleberg 1989), but also of reduced physiological activity in a semi-dormant state (Novitsky \& Morita 1977). The current literature discussion about the physiology of 'viable but non-culturable cells' (cf. Bloomfield et al 1998) demonstrates the lack of knowledge about the rate of physiological activity at low growth rates. An empirical lower limit for the application of the Pirt model could be defined as $0.01 \mathrm{~d}^{-1}$; this is slightly lower than the lowest published rate in the data applied here. Other boundary conditions for the model would constitute those conditions that would change the growth yield or the specific respiration rate independent of the growth rate. These conditions might include the accumulation of storage material, or the production of extra-cellular polymeric matrices. Several factors have been suggested to change the specific respiration rate, such as viral infection (Middelboe et al. 1996), the degree of substrate reduction (Vallino et al. 1996), temperature (Sherr \& Sherr 1996), the C/N ratio (Goldman et al. 1987, Goldman \& Dennet

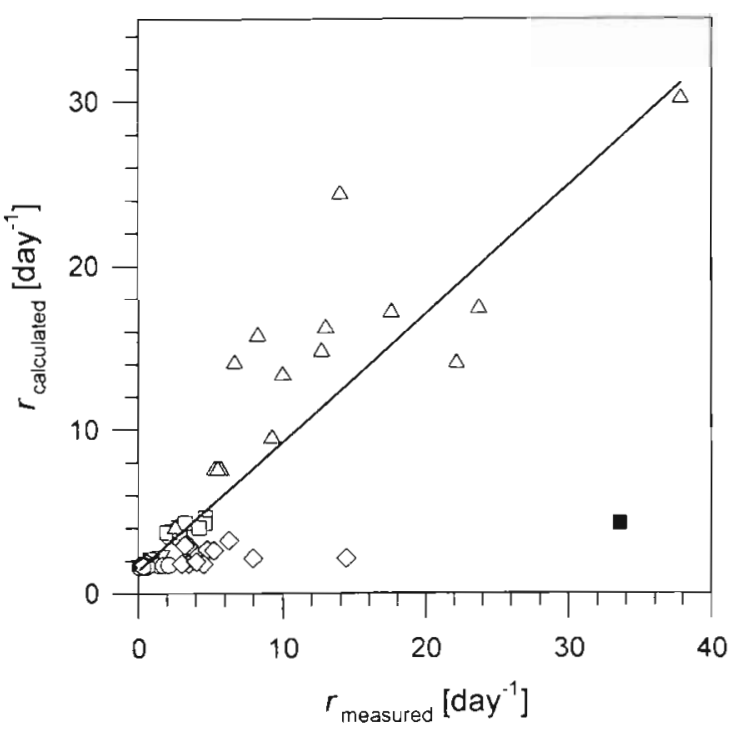

Fig. 5. Comparison of measured and modeled respiration rate. Linear regression yielded a $\mathrm{r}^{2}=0.77(\mathrm{n}=75, \mathrm{p}<0.01)$. The intercept and slope are not significantly different from 0 and 1 respectively. Symbols are the same as in Fig. 2

1991, Kroer 1993), addition of ammonium (Kroer 1993), inorganic nutrient limitation (Pirt 1982, Zweifel et al. 1993), oxygen partial pressure (Pirt 1975), and the excretion of organic polymers (Neijssel et al. 1996). When the Pirt model is applied to a combination of different published data sets, it has to be assumed that these data were taken under organic substrate limitation and that the above listed environmental factors did not modify the bacterial growth efficiency to a significant degree.

The data in Fig. 2 follow an asymptotic curve as expected from the Pirt model, with the growth efficiency approaching $\varepsilon$ at high growth rates. Despite the different methods applied to obtain the data sets (Table 1), the model seems to fit the data quite well. At low growth rates the growth efficiency increases steeply. Small errors in the estimation of specific growth rate could explain much of the noise in the data in Fig. 2. The differences between data sets can be due to the type of methods applied (Table 1). These differences are difficult to evaluate quantitatively. Also, different conversion factors have been applied by the authors (Table 1), e.g. for the RQ or the conversion factors from cells to cellular carbon. One example how the results of 2 different methods based on either biovolume or cell counts to estimate growth rate can give significantly different values is given by Carlson \& Ducklow (1996). When the growth rate data based on biovolume were entered into the model analysis, more data dispersion and generally higher estimates were found than with growth rate based on cell counts. Sim- 


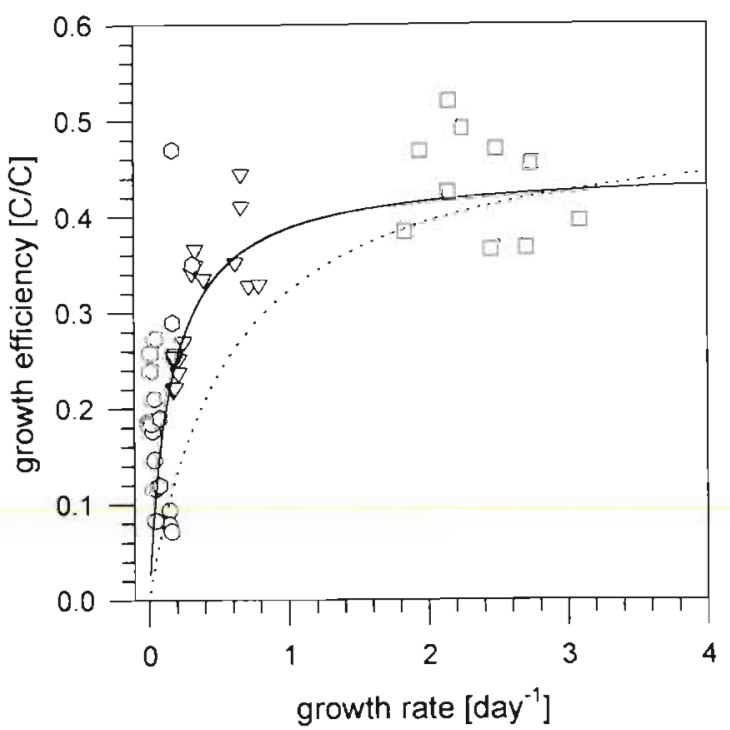

Fig. 6. Growth efficiency and specific growth rate of the data published by Blum \& Mills (1991), Middelboe et al. (1992), Middelboe \& Sondergaard (1993) and Kristiansen et al. (1992). (-) Modeled relationship calculated with $a=0.16$ and $\varepsilon=0.4(\mathrm{n}=49)$. ( $\cdots)$ Modeled relationship for all data (Fig. 2) with $a=0.58$ and $\varepsilon=0.51$. Symbols are the same as in Fig. 2

ilarly Troussellier et al. (1997) found that the conversion factor cell carbon per cell is more constant than the carbon per cell volume. The above discrepancies are pointed out here to demonstrate that much of the noise in Fig. 2 is probably methodological and not biological.

The most salient features of the Pirt model are the assumption of a constant maintenance respiration, $a / \varepsilon$, and a growth rate dependent respiration term, $(1 / \varepsilon-$ 1) $\mu$. The concept of maintenance respiration was introduced by Pirt (1965) and since then it has been supported by others (Koch 1997). There is some evidence that the value for the maintenance energy can be a large portion of the total cellular energy budget (Pirt 1982), but no typical value for maintenance energy in different physiological situations including those in the ocean ecosystem are known. Morita (1997) and others have questioned the existence of significant maintenance respiration because bacteria can survive low nutrient environments for many days without loss of biomass. As mentioned above, the Pirt model should not be applied to extremely low growth rates because of the ill-defined physiological state. In the range of measurable growth rates, it can be assumed that some energy generated from the oxidation of organic carbon must be spent on the maintenance of cell integrity and viability (e.g. turnover of macromolecules, maintenance of ion gradients, motility, etc.). Neijssel et al. (1996) suggested that a partial uncoupling of catabo-

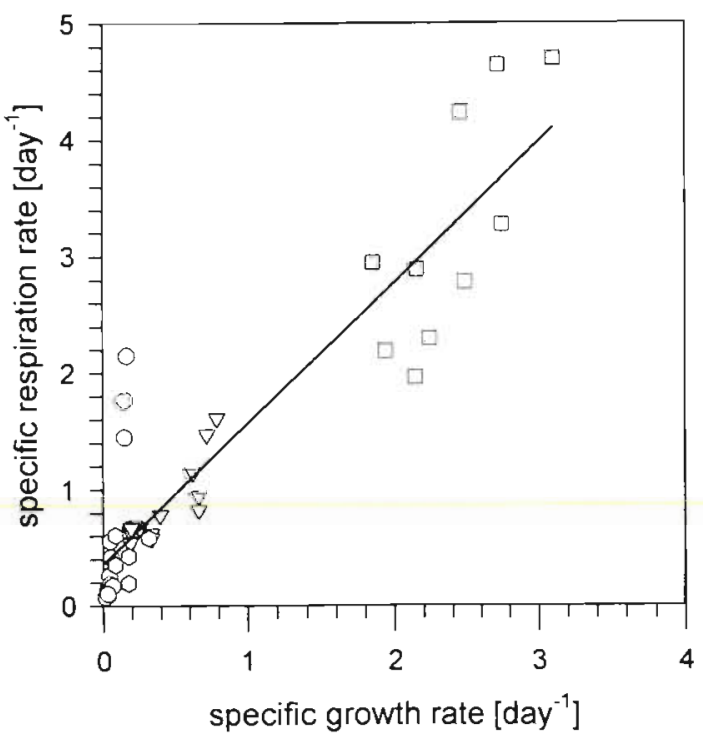

Fig. 7. Respiration versus growth rate based on the data by Blum \& Mills (1991), Middelboe et al. (1992), Middelboe \& Søndergaard (1993) and Kristiansen et al. (1992). The regression line yielded $a=0.16$ and $\varepsilon=0.4\left(\mathrm{r}^{2}=0.85, \mathrm{n}=49, \mathrm{p}<\right.$ $0.01)$. The intercept and slope are not significantly different from 0 and 1 respectively. Symbols are the same as in Fig. 2

lism from anabolism may influence the variability of a for a certain bacterial population. In Fig. 1 the direct conversion of substrate is indicated by a broken arrow. If this metabolic route would become quantitatively significant compared to the respiration of the substrate, then the biosynthesis metabolism (solid line circle, Fig. 1) would have to be modeled with an $\varepsilon$ that would be higher than the $\varepsilon$ for the maintenance metabolism (gray line circle, Fig. 1).

In Fig. 2 the different data sets show little overlap in growth rates. The data would represent the model better if single data sets would cover a greater range of growth rates. The asymptotic pattern of the data in Fig. 2 is largely supported by the high growth rate data from Goldman \& Dennet (1991), because most of the other data lie in the region of low growth rates $\left(<4 \mathrm{~d}^{-1}\right)$ and strongly variable growth yield. A subset of data without the Goldman \& Dennet (1991) data can only be modeled with statistical significance if the data by Carlson \& Ducklow (1996) and 1 outlier data point by Middelboe \& Søndergaard (1993) are also excluded from the data (Fig. 6). The regression of $r$ against $\mu$ of this reduced data set (Fig. 7) yielded a determination coefficient of $0.85(n=49, p<0.01)$. The estimate of the $\varepsilon=0.45$ and $a=0.16$ parameters are somewhat different from the parameters estimated from the complete data set. The statistical significance of this reduced data set demonstrates that the general model behavior is supported by the data set without the data by Gold- 
man \& Dennet (1991). When the single data sets are tested by themselves, only the data from Middelboe et al. (1992) resulted in a statistically significant regression between $r$ and $\mu$, yielding a determination coefficient of $0.76(\mathrm{n}=18, \mathrm{p}<0.01)$. The estimate of $\varepsilon$ and $a$ from the slope and intercept of this regression are 0.44 and 0.13 respectively. In the 3 cases calculated here, $\varepsilon$, the maximum attainable growth efficiency, was similar: $0.5,0.45,0.44$. These value are close to the average value extracted from a review of literature values (Cole \& Pace 1995), and they are not very different from the maximum growth yields reported for glucose or other monomeric organic substrates (Pirt 1975). In natural waters the dissolved organic substrate might be expected to yield lower growth efficiencies, because it is probably less reduced and more difficult to assimilate due to the steric configuration of the substrate molecules, but this might be compensated by the uptake of different and complementary molecules. Novitzky \& Karl (1985) among others reported higher growth efficiencies for natural benthic bacterial populations. At this moment the data are insufficient to explain growth efficiencies above 0.5. There are environmental conditions known to reduce the growth efficiency in Eq. (14), e.g. inorganic nutrient limitation (Pirt 1982) and probably also higher temperature. Under inorganic nutrient limitation, $r$ should increase at lower growth rates, i.e. under stronger inorganic nutrient limitation (Pirt 1982), which is the opposite trend to Eqs. (14) \& (13). The data from Carlson \& Ducklow (1996) (Fig. 2) could be best modeled with a higher maintenance respiration rate and therefore it might be argued that these data were taken under conditions of inorganic nutrient limitation. In fact Carlson \& Ducklow (1996) suggest that during their experiments a secondary nutrient limitation might have occurred. The authors also discussed the relatively low growth efficiency obtained in their experiments, and the dependence of these values on the conversion factor $\left(f_{4}\right.$, Table 1). Both the inorganic nutrient limitation or the conversion factor might explain the divergence of the Carlson \& Ducklow (1996) data from the general trend of the other data, but given the limited data and the general lack of information on the physiology of growth efficiency, there is no sufficient basis for a comparative discussion of the data sets.

The growth efficiency function is dependent on the respiration rate. Temperature in turn has a pronounced effect on the respiration rate and therefore can be expected to affect growth efficiency. Some authors have found a linear correlation between growth efficiency and temperature that was positive (Barillier \& Garnier 1993), negative (Daneri et al. 1994), or did not show any correlation at all (Kroer 1993). The temperature in the present literature data set ranged from 10 to $25^{\circ} \mathrm{C}$ showing no obvious co-variation with growth efficiency; however, increased respiratory activity is expected with a temperature increase (Sherr \& Sherr 1996). In general it is not known if respiration and substrate uptake are affected in different ways because of technical difficulties to separate the effect of substrate and temperature

The maintenance respiration, given by $a / \varepsilon$ from these 3 different estimates, was $1.14,0.36$, and 0.3 respectively, for the total data set, the reduced data set and Middelboe et al. (1992). These considerable differences can partially be explained by the errors in the growth rate and the yield estimate. But it can also be expected that there are considerable physiological differences at very low growth rates, as mentioned above, and there is no consensus at this moment under what conditions the physiological activity is changing and on what scales. The Pirt model can estimate the specific respiration rate at different growth rates, even if the natural bacterial community is composed of different physiological fractions, e.g. a growing and a viable but non-growing fraction (Kogure et al. 1987, Roszak \& Colwell 1987, Zweifel \& Hagström 1995, Joux \& LeBaron 1997). The community metabolism can then be calculated from the biomass ratios and the specific growth rates of each fraction, but only if the same $\varepsilon$ and a would apply to the different physiological fractions.

One underlying assumption in the analysis above is a constant quality of the organic substrate and hence a constant growth efficiency. The effect of the quality of the organic substrate on bacterial utilization of organic carbon was investigated by Vallino et al. (1996). They extracted from the literature the following relationships of the state of reduction of the limiting organic substrate $(\varphi)$ to the maximum growth rate (Eq. 15) and to the growth yield at maximum growth rate (Eq. 16):

$$
\begin{gathered}
\mu_{\max }=0.18 \varphi^{2} \\
Y=0.17 \varphi-0.038
\end{gathered}
$$

If Eq. (15) is substituted into Eq. (16) a relationship of $Y$ versus $\mu_{\max }$ under unlimited substrate concentrations is found (Fig. 8). Eqs. (15) \& (16) should only be valid at growth rates $<6.0 \mathrm{~d}^{-1}$ because at higher growth rates the growth efficiency would exceed 1. Fig. 8 is fundamentally different from Fig. 2 because Fig. 8 is valid for growth conditions unlimited by the concentration of specific substrates, but limited by the quality of the substrate, whereas Fig. 2 is valid for growth conditions limited by the concentration of organic substrate. Theoretically Fig. 8 should describe an outer envelope, and the $Y$ versus $\mu$ curves obtained for different substrate types should apply only to growth rates below the curve in Fig. 6. This is obviously not the case in Fig. 2, where the maximum $Y$ of 0.5 is relatively low, but this $Y$ is obtained at much higher growth rates than 


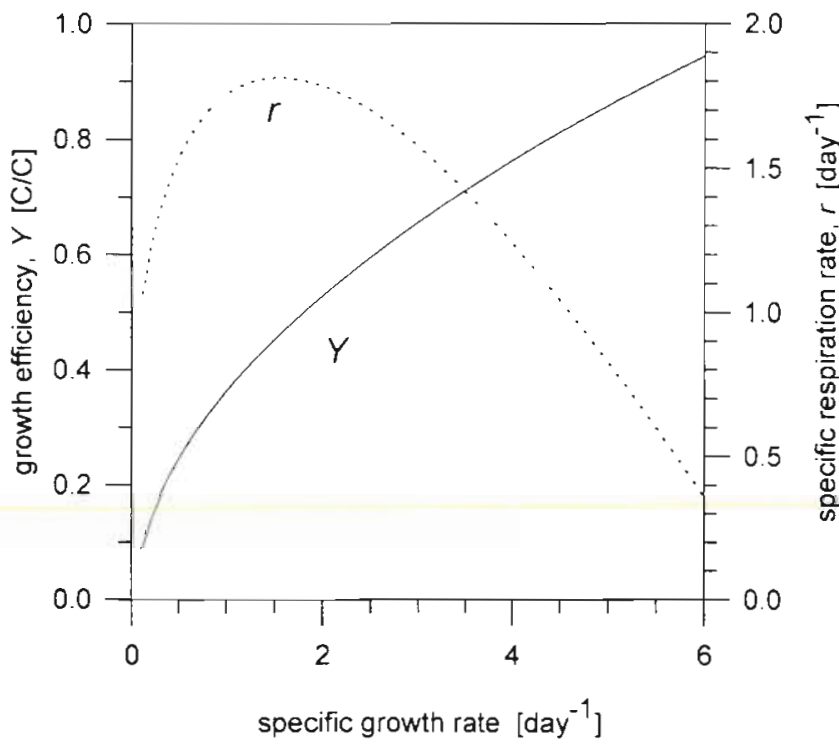

Fig. 8. Growth efficiency and specific respiration rate versus maximum specific growth rate (Vallino et al. 1996)

in Fig. 8. The difference might be explained partly by the noisy data from which Eqs. (15) \& (16) were derived (Vallino et al. 1996). In addition, the bacteria in most of the data sets analyzed by us were growing on multiple substrates, whereas the data in Fig. 8 were obtained from cultures supplied with single substrates. There is an obvious need for further research to resolve this difference.

There are few data available in the literature describing the general relationship of growth efficiency, specific growth rate and $\mathrm{CO}_{2}$ respiration of heterotrophic aquatic bacteria. The limited number of data sets analyzed here were obtained with various methods, but still a general pattern can be observed. We are proposing that, within a limited temperature range of approximately 10 to $25^{\circ} \mathrm{C}$, this general pattern can be explained by the Pirt model, and Eqs. (6) \& (12) can be applied to ecosystem models for regions where the bacterial growth rate is not limited by inorganic nutrients. There is an obvious need for more growth yield data obtained with natural populations and these future data will show to what extent parameters other than growth rate, as outlined above, will modify the general pattern.

Acknowledgements. The research was supported by the Mexican granting agency CONACyT, grant no. 3588-T and by Universidad Autónoma de Baja California, grant no. 13583. We are grateful to Dr Farooq Azam for reading an early version of this manuscript, to Dr Hugh Ducklow and 3 other anonymous reviewers for constructive comments and criticism.

\section{LITERATURE CITED}

Barillier A, Garnier J (1993) Influence of temperature and substrate concentration on bacterial growth yield in Seine river water batch cultures. Appl Environ Microbiol 59: $1678-1682$

Bloomfield SF, Stewart GSAB, Dodd CER, Booth IR, Power EGM (1998) The viable but non-culturable phenomenon explained? Microbiology 144:1-2

Blum LK, Mills AL (1991) Microbial growth and activity during the initial stages of seagrass decomposition. Mar Ecol Prog Ser 70:73-82

Carlson CA, Ducklow HW (1996) Growth of bacterioplankton and consumption of dissolved organic carbon in the Sargasso Sea. Aquat Microbiol Ecol 10:69-85

Cole JJ, Pace ML (1995) Why measure bacterial production? A reply to the comment by Jahnke and Craven. Limnol Oceanogr 40:441-444

Daneri G, Riemann B, Williams PJleB (1994) In situ bacterial production and growth yield measured by thymidine, leucine and fractionated dark oxygen uptake. J Plankton Res 16:105-113

Goldman J. Dennet MR (1991) Ammonium regeneration and carbon utilization by marine bacteria grown on mixed substrates. Mar Biol 109:369-378

Goldman J, Caron DA, Dennet MR (1987) Regulation of gross growth efficiency and ammonium regeneration in bacteria by substrate $\mathrm{C}: \mathrm{N}$ ratio. Limnol Oceanogr 32 : $1239-1252$

Horrigan SG, Hagström $\AA$, Koike I, Azam F (1988) Inorganic nitrogen utilization by assemblages of marine bacteria in seawater culture. Mar Ecol Prog Ser 50:147-150

Jahnke RA, Craven DB (1995) Quantifying the role of heterotrophic bacteria in the carbon cycle: a need for respiration rate measurements. Limnol Oceanogr 40:436-441

Joux F, LeBaron P (1997) Ecological implications of an improved direct viable count method for aquatic bacteria. Appl Environ Microbiol 63:3643-3647

Jumars PA (1993) Concepts in biological oceanography. Oxford University Press, New York

Koch LA (1997) Microbial physiology and ecology of slow growth. Microbiol Mol Biol Rev 61:305-318

Kogure K, Simidu U, Tag N, Colwell RR (1987) Correlation of direct viable count with heterotrophic activity for marine bacteria. Appl Environ Microbiol 53:2332-2337

Kristiansen K, Nielsen $H$, Riemann B, Fuhrman JA (1992) Growth efficiencies of freshwater bacterioplankton. Microb Ecol 24:145-160

Kroer N (1993) Bacterial growth efficiency on natural dissolved organic matter. Limnol Oceanogr 38:1282-1290

Kuparinen J, Heinänen A (1993) Inorganic nutrient and carbon controlled bacterioplankton growth in the Baltic Sea. Estuar Coast Shelf Sci 57:271-285

Middelboe M, Søndergaard M (1993) Bacterioplankton growth yield: seasonal variations and coupling to substrate lability and -glucosidase activity. Appl Environ Microbiol 59:3916-3921

Middelboe M, Nielsen B, Sendergaard M (1992) Bacterial utilization of dissolved organic carbon (DOC) in coastal waters - determination of growth yield. Arch Hydrobiol Beih Ergebn Limnol 37:51-61

Middelboe M, Jørgensen NO, Kroer N (1996) Effects of viruses on nutrient turnover and growth efficiency of noninfected marine bacterioplancton. Appl Environ Microbiol 62:1991-1997

Morita RY (1997) Bacteria in oligotrophic environments. Chapman \& Hall, Ltd, London 
Neijssel OM, Teixeira de Mattos JM, Tempest DW (1996) Growth yield and energy distribution. In: Neidhardt $F$ and 9 others (eds) Escherichia coli and Salmonella cellular and molecular biology, 2nd edn. ASM Press, Washington, DC, p 1683-1691

Novitsky JA, Karl DM (1985) Influence of deep ocean sewage outfalls in the microbial activity of the surounding sediment. Appl Environ Microbiol 50:1464-1473

Novitsky JA, Morita RY (1977) Survival of a psychrophilic marine Vibrio under long term nutrient starvation. Appl Environ Microbiol 33:635-641

Nyström T, Kjelleberg S (1989) Role of protein synthesis in the cell division and starvation induced resistance to autolysis of a marine Vibrio during the initial phase of starvation. J Gen Microbiol 135:1599-1606

Pirt SJ (1965) The maintenance energy of bacteria in growing cultures. Proc R Soc Lond Ser B 163:224-231

Pirt SJ (1975) Principles of microbe and cell cultivation. John Wiley and Sons, New York

Pirt SJ (1982) Maintenance energy: a general model for energy-limited and energy sufficient growth. Arch Microbiol 133:300-302

Rivkin RB, Anderson RM (1997) Inorganic nutrient limitation of oceanic bacterioplankton. Limnol Oceanogr 42:730-740

Editorial responsibility: Frede Thingstad,

Bergen, Norway
Roszak DB, Colwell RR (1987) Metabolic activity of bacterial cells enumerated by direct viable count. Appl Environ Microbiol 53:2889-2893

Sherr EB, Sherr BF (1996) Temporal offset in oceanic production and respiration processes implied by seasonal changes in atmospheric oxygen: the role of heterotrophic microbes. Aquat Microbiol Ecol 11:91-100

Thingstad FT (1987) Utilization of N, P, and organic C by heterotrophic bacteria. I. Outline of a chemostat theory with a consistent concept of 'maintenance' metabolism. Mar Ecol Prog Ser 35:99-109

Troussellier M, Bouvy M, Courties C, Dupuy C (1997) Variation of carbon content among bacterial species under starvation condition. Aquat Microb Ecol 13:113-119

Vallino JJ, Hopkinson CS, Hobbie JE (1996) Modeling bacterial utilization of dissolved organic matter: optimization replaces Monod growth kinetics. Limnol Oceanogr 41: $1591-1609$

Zweifel UL, Hagström $\AA$ (1995) Total counts of marine bacteria include a large fraction of non-nucleoid-containing bacteria (ghosts). Appl Environ Microbiol 61:2180-2185

Zweifel UL, Norrman B, Hagström $\AA$ (1993) Consumption of dissolved organic carbon by marine bacteria and demand for inorganic nutrients. Mar Ecol Prog Ser 101:23-32

Submitted: May 29, 1998; Accepted: November 26, 1998

Proofs received from author(s): June 29, 1999 